\title{
Dos jardines de la modernidad: India en Octavio Paz
}

\author{
Two Gardens of Modernity: \\ India in the Work of Octavio Paz
}

\section{CARLOS EDUARDO LÓPEZ CAFAGGI*}

Resumen: Este artículo indaga en la percepción que Octavio Paz tenía sobre India, ahondando en su experiencia personal como viajero $y$, eventualmente, embajador de México en este país. La mayor parte del texto cuestiona, mediante la teoría poscolonial, el sesgo eurocéntrico que el escritor mexicano reproduce en Vislumbres de la India. Además, hago una revisión crítica de su poemario Ladera este, contrastando en ambos casos la afinidad y la distancia del poeta hacia su sujeto de estudio y devoción. El propósito de este trabajo no es sólo destacar la importancia que India tenía en Octavio Paz (un elemento a menudo olvidado en la crítica literaria), sino también evaluar estética y académicamente sus acercamientos a ella.

Palabras clave: Octavio Paz; India; orientalismo; literatura de viajes.

Abstract: This article focuses on the ways Octavio Paz perceived India and the biographical factors that influenced his judgements - particularly, his voyages to the subcontinent, first as a tourist and then as Ambassador of Mexico. This text attempts, firts and foremost, to draw on postcolonial theory to examine Paz's Eurocentric approach in his essay Vislumbres de la India. I also examine critically his collection of poems Ladera este. This comparison seeks to contrast the affinity and distance of the poet towards his subject of study and

Recepción: 20 de mayo de 2016. / Aceptación: 3 de agosto de 2016.

* El Colegio de México, A.C., celopez@colmex.mx 
devotion. The purpose of this article is dual: to emphasize the importance of India in Octavio Paz's work (often overlooked by literary critics) and to evaluate his approaches aesthetically and academically.

Key words: Octavio Paz; India; orientalism; travel literature.

Cada ciudad recibe su forma del desierto al que se opone.

ITALO CALVINO ${ }^{1}$

Dos o tres pájaros inventan un jardín.

Octavio Paz ${ }^{2}$

\section{Introducción}

Octavio Paz visitó el subcontinente indio por primera vez en noviembre de 1951, mientras fungía como tercer secretario en la embajada de México en París. En las páginas iniciales de Vislumbres de la India (1995), el escritor narra su encuentro con esta tierra de fantasía imaginada. A bordo del Battory, minutos antes de llegar a tierra, contempló la arquitectura ondulada en el horizonte, jirones de nubes rosadas y bandadas de pájaros sobre arcos de piedra, hasta que finalmente avistó la silueta del hotel Taj Mahal, "enorme pastel, delirio de un Oriente finisecular, caído como una gigantesca pompa no de jabón sino de piedra en el regazo de Bombay”. Al advertir su asombro, un ingeniero a

${ }^{1}$ Italo Calvino, Las ciudades invisibles, $23^{\text {a }}$ ed., tr. A. Bernárdez, Madrid, Siruela, 2013, p. 33.

${ }^{2}$ Octavio Paz, "Viento entero", en Ladera este (1962-1968), $5^{\text {a }}$ ed., México, Joaquín Mortiz, 1998, p. 102. En adelante, citada sólo como Ladera este. He decidido utilizar esta edición corregida, ya que es semejante a la versión incluida en las Obras completas que el escritor supervisó (Octavio Paz, Obras completas VII: Obra poética [1935-1998], $2^{\mathrm{a}}$ ed., Barcelona, Galaxia Gutenberg, 2004). Hay diferencias significativas entre esta versión del poemario y su primera edición de 1969 (Octavio Paz, Ladera este, México, Joaquín Mortiz, 1969): en la primera versión impera el uso de mayúsculas al comienzo de cada verso, mientras que en las reimpresiones y en las Obras completas la mayor parte de los versos inicia con minúsculas, y las mayúsculas se utilizan selectivamente, para separar ideas e influjos. Un ejemplo en "La exclamación”: "Quieto/No en la rama/En el aire/ No en el aire/En el instante/El colibrí” (ed. de 1969); “Quieto/no en la rama/ en el aire/No en el aire/en el instante/el colibrí” (ed. de 1998). 
bordo, quien casualmente era hermano del poeta W. H. Auden, le comentó al escritor mexicano que los constructores habían leído mal los planos, por lo que erigieron el edificio al revés, dando la espalda al mar, en vez de a la ciudad. La respuesta de Paz resume el criterio orientalista, las antinomias coloniales y los lazos tendidos entre hemisferios que permean el resto del libro: "El error me pareció un 'acto fallido' que delataba una negación inconsciente de Europa y la voluntad de internarse para siempre en la India. Un gesto simbólico, algo así como la quema de las naves de Cortés. ¿Cuántos habríamos experimentado esta tentación?”. ${ }^{3}$

\section{La inmensa realidad}

"La India es una gigantesca caldera y aquel que cae en ella no sale nunca”, escribió Octavio Paz en 1967. ${ }^{4}$ Cinco años antes, había recibido el puesto de embajador de México en India como castigo orquestado por Jaime Torres Bodet, director general de la UNESCO, y Manuel Tello, ministro de Relaciones Exteriores, ambos angustiados debido a activismo político en Francia. Aunque la idea era deshacerse del escritor trasladándolo a un país "de segunda clase", los seis años que vivió en el subcontinente fueron, en sus palabras, "una educación sentimental, artística y espiritual", que definió el resto de su vida y su obra. En virtud de su aprendizaje estético y de su matrimonio con Marie José, el poeta definiría la experiencia como un "segundo nacimiento". ${ }^{5}$ Con ánimo de polemizar, el filólogo e indólogo Adrián Muñoz García sostiene que la influencia de India fue "un factor mucho más relevante y duradero que el surrealismo" en su quehacer literario, a pesar de su clara ausencia en la crítica hispánica. ${ }^{6}$ Las reflexiones y las apreciaciones de Paz al

${ }^{3}$ Octavio Paz, Vislumbres de la India, Barcelona, Seix Barral, 1995, pp. 5-12.

${ }^{4}$ Octavio Paz, Claude Lévi-Strauss o el nuevo festín de Esopo, México, Joaquín Mortiz, 1967, p. 83, cit. por Manuel Durán, "La huella del Oriente en la poesía de Octavio Paz”, Revista Iberoamericana, vol. 37, núm. 74, 1971, p. 97.

${ }_{6}^{5}$ Paz, Vislumbres de la India, op. cit., pp. 7- 26.

6 "Hasta la fecha ha sido más bien escaso el intento de valorar las maneras en que la India ha influido en la obra de Paz, en parte quizá por la falta de especialistas hispánicos en historia o cultura indias que puedan tender el puente entre el subcontinente 
respecto quedaron cristalizadas en Ladera este (1969), Conjunciones y disyunciones (1969), El mono gramático (1974) y Vislumbres de la India (1995), entre otros. Este último es el tema que aquí acontece, ya que en esta obra el ensayista mexicano plasmó con mayor claridad y detenimiento su percepción de la historia india, su presente y posible futuro.

En 1984, Octavio Paz se encontraba en camino a Delhi para dar una conferencia en memoria del ex primer ministro Jawaharlal Nehru, a petición de Indira Gandhi. Desafortunadamente, tras su asesinato y los disturbios generalizados que le sucedieron, la invitación se vio frustrada. Al año siguiente, el escritor impartió su conferencia gracias a la reiterada solicitud de Rajiv Gandhi, nuevo primer ministro e hijo de Indira. Una década después, el ex embajador tropezó con las páginas que había preparado y decidió extenderlas. Vislumbres de la India fue fruto del destino aunado a su nostalgia, un ensayo que, según dice, buscaba responder la pregunta: “¿Cómo ve un escritor mexicano, a fines del siglo xx, la inmensa realidad de la India?". Consciente de la ambición y subjetividad que tal empresa acarrea, Paz sostiene que el título del libro resume su carácter, ya que sólo lograría aportar vislumbres, “indicios, realidades percibidas entre la luz y la sombra”. ' Debo concordar con su declaración de impotencia o humildad. Debido al marcado orientalismo del intelectual mexicano y las nociones viciadas que su obra reproduce sobre "el Este", sus bosquejos de India no logran aprehender la identidad del sujeto en cuestión,

asiático y el autor mexicano [...] Son aproximaciones como la de Eliot Weinberger (1991), uno de los principales traductores de Paz al inglés, las que permiten valorar más profundamente el arraigo índico en Paz. Por desgracia, la crítica hispánica ha sido aún poco fecunda al respecto y se ha limitado solamente a mencionar la existencia de una influencia india u oriental” (Adrián Muñoz García, "Vislumbres del Oriente, o la India traducida por Paz", en Xicoténcatl Martínez Ruiz y Daffny Rosado Moreno [coords.], Festines y ayunos. Ensayos en homenaje a Octavio Paz (1914-2014), México, Instituto Politécnico Nacional, 2014, pp. 113-115). Quizá se ha prestado más atención a la relación del poeta con el Lejano Oriente, como demuestra el reciente compendio de Aurelio Asiain (ed.), Japón en Octavio Paz, México, Fondo de Cultura Económica, 2014. Recientemente, Hervé-Pierre Lambert publicó Octavio Paz et l'Orient, París, Classiques Garnier, 2014, volumen que analiza minuciosamente la relación de Paz con los orientes en perspectiva comparada. Por cuestiones de disponibilidad, no se ha incluido en la bibliografía.

7 Paz, Vislumbres de la India, op. cit., pp. 40-43. 
aunque permiten elucidar la naturaleza de algunos conceptos en el resto de su obra.

\section{Orientalismos diferenciados}

La hispanista india Malabika Bhattacharya elogia la forma en que Octavio Paz "penetró la máscara turística que [los indios] se ponen frente a los forasteros", logrando adentrarse en su psique gracias a su afición al tantrismo y su comprensión del budismo, a diferencia de su mentor André Breton y demás surrealistas, quienes veían en el Este un "enigma indescifrable [...] música distante, mundo simbólico". ${ }^{8}$ Los lugares que el escritor visitó, así como su profundo interés en las costumbres y las filosofías indias, revelan la intención de trascender el orientalismo mundano. No obstante, me parece que su obra es un ejemplo - refinado, único e ingenuo-de éste.

En su clásico libro Orientalism, Edward Said definió este concepto como un discurso de dominación, tácita o explícita, basado en "la distinción ontológica y epistemológica" entre Oriente y Occidente; una narrativa de otredad y confrontación sustentada en la "división imaginaria y geográfica" entre puntos cardinales, que contrasta la supuesta racionalidad de Occidente con el barbarismo del Este, el cual se reduce a "esencias" o estereotipos. ${ }^{9}$ Formas de representación estética como la literatura de viajes permitieron difundir la idea de Oriente que sofocaría su realidad en el imaginario europeo. A la acusación romántica de exotismo subyace el sentimiento de superioridad y anhelo de conquista ideológica o material, evidente en los paisajes de Delacroix, el hombre blanco de Kipling o los montes de Darjeeling bajo el lente de Wes Anderson. ${ }^{10}$ Esta contraposición hipotética puede apreciarse en

${ }^{8}$ Malabika Bhattacharya, "Echoes of India: The Poems of Octavio Paz", India International Centre Quarterly, vol. 25, núm. 1, 1989, pp. 1 y ss. Traducción adaptada al contexto de la cita. Todas las traducciones del inglés en el ensayo son mías.

${ }^{9}$ Edward Said, Orientalism, Nueva York, Pantheon, 1978, pp. 31-73 et passim.

${ }^{10}$ Se ha argumentado que The Darjeeling Limited (Estados Unidos, Fox Searchlight Pictures y Collage Cinemagraphique, 2007. Dir. Wes Anderson) es una parodia del orientalismo, pues el filme narra la historia de tres viajeros estadounidenses que supuestamente buscan una experiencia espiritual en India y terminan haciendo todo lo contrario. Véase, por ejemplo, John A. Sweeney, "Postnormal Imaginings in Wes 
la obra de Paz desde Conjunciones y disyunciones, donde el autor define a India como alteridad al declarar que su civilización es "el otro polo de la de Occidente, la otra versión del mundo indoeuropeo". ${ }^{11}$

Si bien el trabajo de Said estudia las construcciones eurocéntricas del mundo árabe, en Imperial Eyes, Mary Louise Pratt analiza jerarquías similares respecto al centro europeo y la periferia de América Latina. ${ }^{12}$ De igual manera, Saurabh Dube considera que esta región ha padecido el mismo discurso de subordinación que el Este, al ser presentada simultáneamente como miembro y ausencia del mundo Occidental, ${ }^{13}$ creencia que Octavio Paz comparte en Postdata, donde llama a los latinoamericanos "gente de las afueras, moradores de los suburbios de la historia [...] los comensales no invitados que se han colado por la puerta trasera de Occidente, los intrusos que han llegado a la modernidad cuando las luces están a punto de apagarse". ${ }^{14}$ En este sentido, al analizar la visión que el ensayista mexicano tenía de India nos adentramos en "un discurso creado desde un 'margen' de la modernidad occidental en torno a otro 'margen", ${ }_{15}^{15}$ el diálogo entre dos exotismos hipotéticos. Aunque el orientalismo de los modernistas hispanoamericanos se inspiró en modelos europeos, éste no refleja la

Anderson's The Darjeeling Limited", East-West Affairs, vol. 2, núm. 1, 2013, pp. 75-98. No obstante, una escena me parece digna de destacarse. Tras haber salvado a un par de niños de una comunidad rural y aislada, los turistas son invitados al funeral del tercero, al que no lograron rescatar. En perfecta simetría, el planosecuencia siguiente traza sus pasos en cámara lenta durante la extraña ceremonia, mientras se escucha Strangers, de The Kinks, cuya letra (“Where are you going? I don't mind/I've killed my world and I've killed my time") parece contraponer la supuesta temporalidad circular de India a la occidental, comparación evidente en la escena siguiente, un flashback sobre el frío luto "occidental".

${ }^{11}$ Octavio Paz, Conjunciones y disyunciones, en Obras completas VI: Ideas y costumbres. La letra y el cetro. Usos y símbolos, Barcelona, Galaxia Gutenberg, 2003, p. 760, cit. por Catalina Quesada Gómez, "De la India a las Indias y viceversa: relaciones literarias entre Hispanoamérica y Asia (siglo xx)”, Iberoamericana. América LatinaEspaña-Portugal, vol. 11, núm. 42, 2011, p. 52. Prescindí de las cursivas que usó el autor.

${ }_{12}$ Mary Louise Pratt, Imperial Eyes: Travel Writing and Transculturation, Nueva York-Londres, Routledge, 1993, pp. 172 y ss.

${ }^{13}$ Saurabh Dube, Modernidad e historia: cuestiones críticas, tr. A. Muñoz, México, El Colegio de México, 2011, p. 10.

${ }_{14}$ Octavio Paz, "Posdata", en El laberinto de la soledad, México, Fondo de Cultura Económica, 2007, p. 215.

${ }^{15}$ Araceli Tinajero, Orientalismo en el modernismo hispanoamericano, West Lafayette, Purdue University Press, 2003, p. 3. 
oposición binaria entre conquistador y subyugado de la relación imperio-colonia a la que alude Said, sino el encuentro de dos sujetos poscolonizados. ${ }^{16} \mathrm{Si}$ bien Paz afirma en Conjunciones $y$ disyunciones que "la relación entre India y Occidente es la de una oposición dentro de un sistema", ${ }^{17}$ Julia Kushigian nota que la variación latinoamericana del orientalismo se distingue del europeo por la forma en que tales opuestos se unen y entremezclan. ${ }^{18}$

Así pues, en Vislumbres de la India, Paz se identifica con el subcontinente en vez de antagonizarlo. Buscando distanciarse de la "locación estratégica" de autoridad generalmente asociada al discurso orientalista, el autor exalta su condición paralela: ${ }^{19}$ "La extrañeza de la India suscitaba en mi mente la otra extrañeza, la de mi propio país [...], mi propio e íntimo exotismo de mexicano". ${ }^{20}$ El viajero encuentra en esta tierra de misticismo y calor opresivo un correlato de la historia mexicana, así que a menudo pretende trazar semejanzas y coincidencias entre ambas culturas. Por ejemplo, al contemplar el paisaje desolado que se disipaba en el horizonte en camino a Delhi, Paz evocó imágenes borrosas de su infancia: viajes en ferrocarril durante los últimos días de la Revolución mexicana, en que, apenas a los seis años, contempló hombres ahorcados balanceándose bajo los postes del telégrafo a lo largo de la vía. Estos bosquejos del pa-

${ }^{16}$ Ibid., p. 9.

${ }_{17} \mathrm{Paz}$, Conjunciones y disyunciones, p. 760, cit. por Quesada Gómez, "De la India a las Indias y viceversa”, op. cit., p. 52.

${ }^{18}$ Julia A. Kushigian, “Ríos en la noche: fluyen los jardines': Orientalism in the Work of Octavio Paz”, Hispania, vol. 70, núm. 4, 1987, p. 785, nota 1.

${ }^{19}$ Susan Briante, "Dwelling and Travel: Octavio Paz and El mono gramático", TRANS-, núm. 5, 31 de enero de 2008. Este texto estudia El mono gramático como parte de la tradición surrealista de literatura de viajes. La conclusión de la autora es semejante a lo que más adelante comentaré sobre Ladera este: aunque en su obra poética Paz logra subvertir la posición de autoridad que caracteriza al orientalismo tradicional, su criterio en Vislumbres de la India es más cercano al que Said denuncia.

20 "Durante los años que viví en la India advertí que entre los indios era muy viva la consciencia de sus diferencias con otros pueblos. Es una actitud que comparten los mexicanos. Una consciencia que no excluye, para los indios, sus diferencias con las naciones del sudeste asiático y, para nosotros, con las naciones latinoamericanas. De ahí que no sea exagerado decir que el hecho de ser mexicano me ayudó a ver las diferencias de la India... desde mis diferencias de mexicano. No son las mismas, por supuesto, pero son un punto de vista; quiero decir, puedo comprender, hasta cierto punto, qué significa ser indio porque soy mexicano" (Paz, Vislumbres de la India, op. cit., pp. 20 y 95$)$. 
sado, a su vez, le invocaron la violencia de la partición del Indostán. ${ }^{21}$ El célebre intelectual acababa de publicar El laberinto de la soledad, donde había intentado exorcizar las pulsiones reprimidas del mexicano para elucidar su identidad; ahora, India presentaba "otra interrogación aún más vasta y enigmática”. ${ }^{22}$ $\mathrm{Y}$, sin embargo, debo hacer dos precisiones sobre la visión del subcontinente que Paz presenta en su obra: aunque el orientalismo latinoamericano es, en cierto sentido, una comparación entre periferias, sujetos subalternos, exotismos contrapuestos, el juicio del escritor está claramente inspirado en el discurso colonial hegemónico, que caracteriza al Este como desviación respecto a la cosmovisión Occidental. Por ello, al intentar resaltar las similitudes entre México e India, usualmente termina reafirmando sus diferencias.

\section{Mierda y jazmines}

Vislumbres de la India se divide en un relato autobiográfico sobre las experiencias de Octavio Paz en ese país y una serie de ensayos sobre su cultura, sociedad y política. Por decirlo así, la obra es una recopilación de vislumbres reales y figurados. Muñoz García dice al respecto: "no es ni un libro de historia ni una bitácora de viajes, aunque una y otra vez el texto parece oscilar entre ambos caminos". ${ }^{23}$ En su recuento inicial no queda claro si su descripción de las ciudades indias acarrea el orientalismo deliberado de poetizar la cotidianeidad o es una simple declaración de asombro. De cualquier manera, el autor reproduce en sus travesías las metageografías dominantes que Dube atribuye a la visión eurocéntrica de la historia universal, entretejida con los procesos del colonialismo y los prejuicios del poscolonialismo. Según esta “cartografía de los espacios encan-

${ }^{21}$ Nótese que una de las pocas alusiones de Paz a su tierra natal en El mono gramático es una viñeta que acarrea otra translocación violenta. En el camino de Galta, el viajero encuentra un perro famélico lamiendo un charco lodoso que un grifo abierto había formado, el cual le invoca la memoria de otro perro que lamía una aureola de sangre alrededor de un muerto en un callejón de un pueblo mexicano (Octavio Paz, El mono gramático, México, Seix Barral, 1974, p. 75).

${ }_{22}^{2}$ Paz, Vislumbres de la India, op. cit., pp. 18-20.

${ }^{23}$ Muñoz, "Vislumbres del Oriente, o la India traducida por Paz", op. cit., p. 120. 
tados", el mundo se divide en sociedades modernas y comunidades tradicionales, categorías que pretenden contraponer la civilidad occidental al barbarismo ajeno. Tal antinomia se refleja en el enfrentamiento de conceptos como "tradición y modernidad, rito y racionalidad, mito e historia, comunidad y Estado, lo mágico y lo moderno, emoción y razón". ${ }^{24}$

Sin embargo, en la pluma de Octavio Paz, tales ideales antagónicos no se neutralizan; al contrario, se alimentan de la realidad inasible de un microcosmos donde las contradicciones del imaginario colonial se entrelazan sin fusionarse. India no es un espacio encantado ni un lugar moderno, sino ambos y ninguno al mismo tiempo, "el realismo descarnado aliado a la fantasía delirante" ${ }^{25}$ Como afirma Juan Carlos Ruiz Guadalajara, el escritor usó la abstracción poética para interpretar la "realidad de extremos y alteridad" que caracteriza a India, entendiéndola "siempre en clave de extremos que se tocan, que se funden, que se explican el uno al otro, que coexisten, se devoran, se necesitan o se rechazan". ${ }^{26}$ Según Paz, esta tierra es un mosaico de contrastes que conviven en extraña armonía: "modernidad y arcaísmo, lujo y pobreza, sensualidad y ascetismo, incuria y eficacia, mansedumbre y violencia, pluralidad de castas y de lenguas, dioses y ritos, costumbres e ideas, ríos y desiertos, llanuras y montañas, ciudades y pueblecillos, la vida rural y la industrial a distancia de siglos en el tiempo y juntas en el espacio". Finalmente sintetiza en retrospectiva: "vi monstruos y me cegaron relámpagos de belleza". ${ }^{27}$

En las primeras páginas de Vislumbres, el viajero recuenta su primera visita a Bombay, ciudad aparentemente caótica y desordenada, quizá en comparación tácita con la disposición racional y sosegada de París, donde había fungido como embajador antes de llegar. A pesar de esta abrupta transición del lugar moderno al espacio encantado, para el intelectual mexicano las viñetas del Este, más que fantásticas, eran demasiado

${ }^{24}$ Saurabh Dube, “Espacios encantados y lugares modernos”, en Saurabh Dube et al. (coords.), Modernidades coloniales: otros pasados, historias presentes, tr. A Bartra, México, El Colegio de México, 2004, pp. 99-118.

${ }^{25}$ Paz, Vislumbres de la India, op. cit., p. 43.

${ }^{26}$ Juan Carlos Ruiz Guadalajara, "Mahatma Gandhi en la mirada de Octavio Paz”, en Martínez Ruiz y Rosado Moreno (coords.), Festines y ayunos, op. cit., p. 88.

${ }^{27}$ Paz, Vislumbres de la India, op. cit., pp. 15 y ss. y 44. 
reales. Al discutir El mono gramático, Fabienne Bradu concluye que en la obra de Paz "la verdadera espiritualidad de la India no consiste en una fuga de la realidad, sino en su revelación por el exceso". ${ }^{28}$ En párrafos consecutivos, el poeta enlista las visiones de la "realidad insólita" que le aguardaba afuera del hotel Taj Mahal:

oleadas de calor, vastos edificios grises y rojos como los de un Londres victoriano crecidos entre las palmeras y los banianos como una pesadilla pertinaz, muros leprosos, anchas y hermosas avenidas, grandes árboles desconocidos, callejas malolientes [...] manchas rojizas de betel en el pavimento, batallas a claxonazos entre un taxi y un autobús polvoriento [...] al cruzar una esquina, la aparición de una muchacha como una flor que se entreabre,

rachas de hedores, materias en descomposición, hálitos de perfumes frescos y puros [...] mujeres de saris rojos, azules, amarillos, colores delirantes, unos solares y otros nocturnos [...] jardines públicos agobiados por el calor, monos en las cornisas de los edificios, mierda y jazmines, niños vagabundos $[\ldots]$

en el cielo, violentamente azul, en círculos o zigzag, los vuelos de gavilanes y buitres, cuervos, cuervos, cuervos... ${ }^{29}$

Al concluir, extenuado, su primera noche en India, Paz colapsó al pie de un gran árbol y resumió su abrumadora experiencia en una cita parafraseada de T. S. Eliot: "Human kind cannot bear much reality". Esta curiosa elección de palabras para englobar una fantasía aparentemente tangible puede entenderse con los conceptos de Dipesh Chakrabarty, quien sostiene que "India" es un "término hiperreal", que alude a "ciertas figuras de la imaginación, cuyos referentes geográficos permanecen más o menos indeterminados". ${ }^{30} \mathrm{Si}$ bien el académico bengalí procura explicar una relación de dominación, la cualidad gráfica de su "India" explica, por ejemplo, que Paz vea en Nueva Delhi "un conjunto de imágenes, más que de edificios". Por instantes, el escritor parece difuminar la brecha entre jerarquías

${ }^{28}$ Fabienne Bradu, "Persistencia de la India en Octavio Paz", en Martínez Ruiz y Rosado Moreno (coords.), Festines y ayunos, op. cit., p. 32.

${ }^{29}$ Paz, Vislumbres de la India, op. cit., pp. 13-15.

${ }^{30}$ Dipesh Chakrabarty, "La poscolonialidad y el artilugio de la historia: ¿quién habla en nombre de los pasados «indios»?", en Saurabh Dube (ed.), Pasados poscoloniales: colección de ensayos sobre la nueva historia y etnografía de la India, tr. G. F. Toriz, México, El Colegio de México, 1999, p. 624. 
hemisféricas al afirmar que la ciudad-jardín es tan "irreal" como las construcciones decimonónicas de Londres; no obstante, en su juicio artístico es clara la atribución de exotismo cuando asigna un dinamismo erótico a las curvas sensuales de Oriente, contrapuesto al carácter rectilíneo de las edificaciones que lo colonizaron: "Se ha dicho que la arquitectura gótica es música petrificada; puede decirse que la arquitectura hindú es danza esculpida". ${ }^{31}$ Tal dinamismo parece reiterativo o incluso atemporal, como el de quien baila sin cesar sobre su propio eje. Bien lo ha dicho Said: uno de los dogmas principales del orientalismo es que el Este es "eterno, uniforme e incapaz de definirse a sí mismo", ${ }^{32}$ idea evidente en "El balcón", desde el que Paz contempla el paisaje:

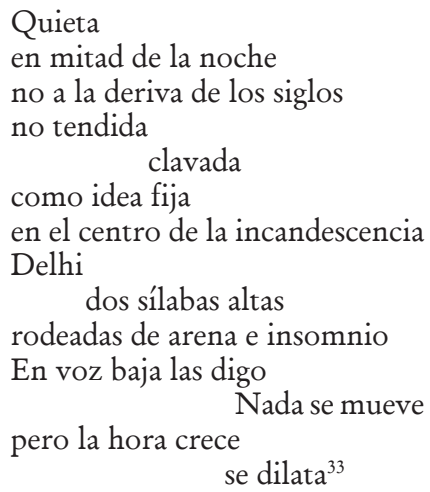

La acusación de atemporalidad también es evidente en la descripción del mausoleo del emperador Humayún, que Paz elogia como la "abolición del tiempo convertido en espacio". ${ }^{34}$ Es difícil negar el orientalismo del escritor, aunque esta sensa-

${ }^{31}$ Paz, Vislumbres de la India, op. cit., pp. 20-26.

${ }^{32}$ Said, Orientalism, op. cit., pp. 300 y ss.

${ }^{33}$ Octavio Paz, "El balcón", en Ladera este, op. cit., p. 11. Este poema muestra las diferencias significativas entre la primera edición del poemario y las subsecuentes. En la versión original, el verso citado dice: "Nada se mueve/Y sin embargo/Crece/ La oleada silenciosa se dilata" (Paz, Ladera este, ed. de 1969, op. cit.). Otro ejemplo de correcciones profundas es el poema "Epitafio de una vieja", en que el autor removió una estrofa entera.

${ }^{34} \mathrm{Paz}$, Vislumbres de la India, op. cit., p. 23. 
ción de intriga espiritual hace de su recuento una crónica brillante y agraciada. En la prosa diáfana del poeta, las estrellas del cielo indio arden silenciosamente y el agua en estanques alargados refleja el mundo al mismo tiempo que lo disipa. La debilidad de Vislumbres es la forma en que esta descripción erotizada de India distorsiona las opiniones del autor sobre su sociedad y sus instituciones.

\section{Especias del tiempo}

Buscando coincidencias en los usos y costumbres de México e India, Octavio Paz se adentra en el territorio del arte culinario y afirma que éste es una de las formas más sinceras para acercarse a la cultura de un pueblo. Según su criterio, los repertorios gastronómicos de ambos países - excéntricos, de sabores y colores violentos- son "infracciones imaginativas y pasionales de los grandes cánones del gusto”. Considera afín la preeminencia del picante en su cocina y admira la semejanza entre el curry y el mole en cuanto a sabor, pigmento y función; sin embargo, encuentra una diferencia significativa en la presentación de los platillos. Utilizando la terminología de Claude Lévi-Strauss, pionero de la antropología estructuralista, Paz sostiene que la cocina mexicana es diacrónica - al igual que la europea, una sucesión de guisos-, mientras que la cocina india es sincrónica: "no sucesión ni desfile, sino aglutinación y superposición de substancias y sabores". Para el ensayista, tal mezcolanza de sabores es un reflejo de su historia, caracterizada por la yuxtaposición de pluralidades religiosas, culturales y sociales, que a menudo se contraponen sin disociarse. ${ }^{35}$ Como argumento de autoridad cita a Jawaharlal Nehru, quien alguna vez equiparó a India con un palimpsesto, en que "uno debajo del otro, están inscritos muchos hechos, ideas y sueños, sin que ninguno de ellos cubra completamente los que están abajo". ${ }^{36}$ En la pluma de Paz, el

${ }^{35}$ Ibid., pp. 87-105.

${ }^{36} \mathrm{Paz}$ no menciona el texto original, pero esta cita se encuentra en el clásico Jawaharlal Nehru, The Discovery of India, Nueva York, The John Day Company, 1946, p. 47. Dice el célebre estadista: "She was like some ancient palimpsest on which layer upon layer of thought and revery had been inscribed, and yet no succeeding layer had 
comentario del estadista alude simultáneamente a la reconciliación de diversidades y a la aparente atemporalidad de India, "fusión de los sabores, fusión de los tiempos". Un inmenso platillo de siglos en putrefacción. ${ }^{37}$

En su impresionante erudición, el premio Nobel observa que "cada civilización es una visión del tiempo", entretejida en sus instituciones, técnicas, filosofías u obras de arte. No obstante, al reconocer esta pluralidad de cosmovisiones, también establece una jerarquía silenciosa en términos de civilidad y barbarismo. Por un lado, el ensayista acierta en afirmar que la idea "moderna" del tiempo rectilíneo se origina en el cristianismo, cuya noción de origen y destino se volvió, al secularizarse, el fundamento de la historia universal, una narrativa de progreso continuo que abarca hasta nuestros días; por el otro, imputa el supuesto estancamiento de India a su "ausencia de conciencia histórica", la cual achaca a la cosmología del hinduismo, que entiende el tiempo como maya: sueño, ilusión, apariencia, "vana repetición de una falsa realidad". Según el poeta, mientras que la Europa moderna enaltece el cambio, India glorifica la inmutabilidad, ya que "la impermanencia es una de las marcas de la imperfección de los seres humanos y, en general, de todos los entes". ${ }^{38}$ Por ello, el poeta considera que el elogio de la atemporalidad permea todo aspecto de India, desde el culto hasta el paisaje, como es evidente en los instantes eternos de "Viento entero":

El presente es perpetuo
Los montes son de hueso y son de nieve
están aquí desde el principio
El viento acaba de nacer
$\quad$ sin edad
como la luz y como el polvo

completely hidden or erased what had been written previously. All of these existed together in our conscious or subconscious selves, though we might not be aware of them, and they had gone to build up the complex and mysterious personality of India".

${ }^{37}$ Paz, Vislumbres de la India, op. cit., pp. 94-102.

${ }^{38}$ Ibid., pp. 44-80.

${ }^{39}$ Paz, "Viento entero", en Ladera este, op. cit., p. 101. 
Más interesante aún es que en Claude Lévi-Strauss o el nuevo festín de Esopo (1967), Paz declara que India y las culturas mesoamericanas comparten esta carencia de conciencia histórica, pues ambas tienen nociones cíclicas del tiempo. ${ }^{40}$ Basta recordar que en El laberinto de la soledad había afirmado que "los antiguos mexicanos" veían el aquí y el más allá como partes de una totalidad dialéctica, porque "la muerte no era el fin natural de la vida, sino fase de un ciclo infinito". ${ }^{41} \mathrm{Al}$ comparar estas concepciones divergentes del tiempo y contraponerlas al tiempo lineal "universal", el orientalista no logra elucidar las dinámicas de poder que su juicio de valor acarrea.

Si bien Paz explica cómo el tiempo sagrado devino historia secular, obvia que la naturalización del tiempo histórico unificó las diferentes narrativas del mundo en una sola cronología que permitió discriminar cosmovisiones ajenas, como él instintivamente lo hace..$^{42}$ De hecho, la carencia de conciencia histórica que el escritor mexicano achaca a India era una noción recurrente entre viajeros y administradores británicos, que permitió reforzar la idea de su estancamiento y atraso. ${ }^{43}$ Para mediados del siglo XIX, quedaba claro que Europa era el epítome de la modernidad, dueña de los instrumentos de su temporalidad, estándar bajo el cual juzgaría y articularía el lenguaje del colonialismo. Tal jerarquía tácita convirtió la división temporal en territorial. ${ }^{44} \mathrm{Ex}$ plica Roger Bartra en La jaula de la melancolía: "el pensamiento occidental llegó a fundir sus nociones del espacio y del tiempo con las ideas del progreso histórico. Así se configuró un estereotipo cultural eurocentrista que llegó a considerar, digámoslo así, que la coordenada temporal iba de oriente a occidente". ${ }^{45}$

${ }^{40} \mathrm{Paz}$, Claude Levi-Strauss o el nuevo festín de Esopo, cit. por Quesada Gómez, "De la India a las Indias y viceversa", op. cit., p. 54.

${ }^{41} \mathrm{Paz}$, El laberinto de la soledad, op. cit., p. 68.

42 Timothy Mitchell, “The Stage of Modernity”, en Timothy Mitchell (ed.), Questions of Modernity, Minneapolis, University of Minnesota Press, 2000, pp. 7 y ss.

${ }^{43}$ Ishita Banerjee-Dube, Religion, Law and Power: Tales of Time in Eastern India, 1860-2000, Londres, Anthem, 2007, pp. 1-8. La autora destaca los hallazgos de estudios recientes, los cuales demuestran que no había una sola concepción del tiempo en la India precolonial y que, además del tiempo cíclico en el Mahabarata, algunas crónicas y genealogías demuestran familiaridad con el tiempo lineal.

${ }^{44}$ Idem.

${ }^{45}$ Roger Bartra, La jaula de la melancolía: identidad y metamorfosis del mexicano, México, Grijalbo, 1987, p. 65. Prescindí de las cursivas que usó el autor. 
Este discurso dicotómico entre modernidad y tradicionalismo no describió el mundo, sino que permitió reinventarlo: Europa era dueña de la historia; India, presa del mito.

Es pertinente rescatar la crítica a la europeización del saber histórico que Chakrabarty denuncia en "La poscolonialidad y el artilugio de la historia", donde lamenta que incluso los estudios actuales sobre el Tercer Mundo tienden a producirse bajo la sombra de Europa, "sujeto de todas las historias". ${ }^{46}$ A pesar de la solidaridad periférica que Paz predica en Vislumbres, gran parte de sus observaciones reproducen los prejuicios del orientalismo decimonónico en sus distintos avatares académicos, distinguiendo tajantemente entre las sociedades occidentales modernas que navegan el flujo de la historia y las no occidentales, ancladas al pasado debido a la importancia del mito y el ritual en sus culturas. Como dice Dube, la modernidad es "el desencantamiento del mundo [...] por medio de poderosas técnicas de la razón", pero también genera sus propios encantamientos, entre ellos las oposiciones jerárquicas que parten al mundo en dos. Tales antinomias permiten que la importancia actual de la espiritualidad hindú y el tradicionalismo indio resulte, a la vez, contemporánea y anacrónica. ${ }^{47}$

Al equiparar la cosmovisión del hinduismo con el tiempo de las culturas prehispánicas, Paz cae en las trampas de la fe ciega en la modernidad. Como bien critica Bartra, la noción de que todos los hombres primitivos comparten una visión homogénea del tiempo es fruto del "racionalismo mecánico anclado en la noción de progreso". ${ }^{48}$ Sea en la arena y el insomnio bajo los que Delhi yace sepultada o en el viento pardo que acaricia la piedra cruda de Luvina, las horas transcurren (o no lo hacen) con igual melancolía. Bartra derriba los cimientos de la cronología universal al revelar que la idea del tiempo mítico "ligado al edén primitivo, en contraste con las nociones modernas del acaecer histórico" es, irónicamente, parte de la mitología moderna. ${ }^{49}$ Así, pues, encontramos un desierto en otro: el tiempo

\footnotetext{
${ }^{46}$ Chakrabarty, "La poscolonialidad y el artilugio de la historia", op. cit., pp. 625 y ss.

${ }^{47}$ Dube, Modernidad e historia, op. cit., pp. 17-28.

${ }^{48}$ Bartra, La jaula de la melancolía, op. cit., p. 68.

${ }^{49}$ Más comentarios al respecto en "El tiempo sin sentido" (ibid., pp. 65-77).
} 
occidental es tan mítico como los que desprecia, pues se centra en narraciones ilusorias que glorifican el progreso, el futuro o la línea recta, tan distante de las curvas del subcontinente, aquella danza hecha piedra.

\section{Castas cristalizadas}

Así como Octavio Paz ve en el hinduismo la "negación metafísica” del tiempo, considera que la institución de las castas es su negación social, un "modelo de organización social pensado para una sociedad estática [...] La casta es ahistórica; su función consiste en oponer a la historia y los cambios una realidad inmutable". ${ }^{50} \mathrm{El}$ ensayista mexicano basa su argumentación en la canónica visión de las castas que el antropólogo francés Louis Dumont articuló en Homo Hierarchicus (1966), a su parecer "la explicación más coherente, original y profunda”. Ignorando las dimensiones políticas y económicas de esta lógica social, Paz denuncia su carácter colectivo y religioso al contraponerlo a la estratificación socioeconómica de las clases sociales modernas. Según su perspectiva, el mayor vicio de las castas es que cristalizan los roles sociales e impiden el progreso individual que el liberalismo occidental abandera: "la casta es lo contrario de nuestras clases y asociaciones, formadas por individuos. En ella la realidad primordial es la colectiva". ${ }^{51}$ No obstante, Paz ignora protestas recientes frente a la inercia del sistema de castas, como el proyecto pacifista que Gandhi abanderó hasta su muerte o la campaña de Ambedkar contra la discriminación de los intocables que conservaba fuerza durante su estadía. ${ }^{52}$

En "Castes of Mind", Nicholas B. Dirks reprocha la forma en que se ha propagado la reputación de la casta como germen de la civilización india, expresión básica de su sociedad, sustento religioso de su origen y reproducción, "una de las razones por las cuales la India carece de historia o, al menos,

${ }^{50} \mathrm{Paz}$, Vislumbres de la India, op. cit., p. 72.

${ }^{51}$ Ibid., p. 71.

${ }^{52}$ Ruiz Guadalajara, "Mahatma Gandhi en la mirada de Octavio Paz", op. cit., pp. 89 y ss. 
de sentido histórico". ${ }^{53}$ En Vislumbres, Paz exagera esta noción primordialista mediante su usual prosa poética, al sostener que esta institución "nació sola, aunque por voluntad divina, cósmica, del suelo y el subsuelo de la sociedad, como una planta [...] Casta es jati y jati es especie. La casta es, por decirlo así, un producto natural".${ }^{54}$ Sin embargo, Dirks considera risible que se haya propagado la imagen de la casta como pilar arcaico del tradicionalismo indio $-\mathrm{y}$, por ende, la mayor amenaza a su modernización-, ya que ésta de hecho permitió allanar el camino para "lo moderno" e incluso se ha exacerbado gracias a instituciones modernas. ${ }^{55}$ No sorprende que el académico enliste el libro de Dumont entre las obras de la antropología moderna que nutrieron la jerarquía imaginada entre Este y Oeste, al describir el Estado precolonial de India como uno débil, a merced de una sociedad guiada por principios religiosos en vez de políticos. ${ }^{56}$ Cuando Paz recrimina que las castas son un obstáculo para la modernización de India, reproduce inconscientemente los postulados de la antropología colonial, que veía en este territorio exótico una sociedad apolítica y renuente al cambio. Dice el ensayista mexicano:

La oposición entre historia y casta se convierte en enemistad mortal cuando la historia asume la forma del progreso y la modernidad. Al hablar de modernidad no me refiero solamente al liberalismo democrático y al socialismo, sino a su rival: el nacionalismo. Las castas constituyen una realidad indiferente a la idea de nación [...] La modernidad, en sus dos direcciones, es incompatible con el sistema de castas. ${ }^{57}$

En realidad, la configuración actual de la casta no es un legado inmemorial "que ha resistido a la civilización moderna, de los ferrocarriles a las fábricas", como afirma Paz, sino una forma moderna de sociedad civil que la administración colonial recreó e instrumentalizó para aglomerar las diversas formas de organización social en India, lo que facilitó su dominación, a la

\footnotetext{
${ }^{53}$ Nicholas B. Dirks, “Castes of Mind”, Representations, vol. 37, núm. 1, 1992, p. 56.

${ }^{54}$ Paz, Vislumbres de la India, op. cit., p. 80.

${ }^{55}$ Dirks, "Castes of Mind", op. cit., pp. 56-61.

${ }^{56}$ Ibid., p. 57.

${ }^{57}$ Paz, Vislumbres de la India, op. cit., pp. 73. Las cursivas son mías.
} 
vez que preservaba el estereotipo de su carácter tradicional. ${ }^{58} \mathrm{En}$ este sentido, las castas no sólo eran "compatibles" con la modernidad; fueron uno de sus instrumentos.

\section{Naciones y negaciones}

Aunque Octavio Paz tuvo una relación cercana a Indira Gandhi durante los seis años que fungió como embajador de México en India, en las páginas de Vislumbres queda claro que concordaba más con el proyecto de nación que su padre, Jawaharlal Nehru, visualizó durante su mandato, hasta el día de su muerte. Paz sólo encuentra elogios para el difunto estadista, a quien caracteriza como un aristócrata pragmático, de "cultura occidental” e inigualable elegancia, "inmaculadamente vestido de blanco y una rosa en el ojal", ${ }^{59}$ a diferencia de Mahatma Gandhi, su contraparte supuestamente espiritual, tradicionalista y retrógrada. ${ }^{60} \mathrm{Al}$ comparar a los padres del Estado indio, Paz deja entrever su apego a la modernidad cuando insinúa que su admiración hacia Nehru se debe a su occidentalismo y, en cierta medida, a su visión de un Estado-nación secular.

${ }^{58}$ Dirks, "Castes of Mind”, op. cit., p. 76.

59 "Al llamarlo aristócrata pienso, primero, en sus orígenes: un brahmán de Cachemira, hijo de un padre célebre y rico, Motilal Nehru; en seguida, en su educación anglicana, que se convirtió en una segunda naturaleza. Nunca habló hindi sino urdu y el hindustani colonial [...] Ni en su pensamiento ni en sus palabras puede encontrarse una huella de simpatía o afinidad con la doble tradición religiosa india, la hindú y la musulmana" (Paz, Vislumbres de la India, op. cit., p. 38). De igual manera, Ashis Nandy categoriza a Nehru como digno representante del secularismo, pues no era creyente ni en su vida privada ni en la pública (Ashis Nandy, "The Politics of Secularism and the Recovery of Religious Toleration”, en Rajeev Bhargava [ed.], Secularism and its Critics, Delhi, Oxford University Press, 1998, p. 328).

${ }^{60}$ Juan Carlos Ruiz Guadalajara afirma que la relación de Paz con Mahatma Gandhi puede entenderse como "el difícil diálogo entre el poeta y el santo". El autor reinterpreta dos citas distintas de Vislumbres de la India en las que, respectivamente, Paz muestra que veía a Gandhi como un santo, más que como un político, y después sostiene que "el diálogo entre el poeta y el santo es difícil porque el primero, antes de hablar, debe oír a los otros, quiero decir, al lenguaje, que es de todos y de nadie; en cambio, el santo habla con Dios o consigo mismo, dos formas de silencio". El autor considera que, en ocasiones, el juicio de Paz sobre Gandhi es simplista y poco original; no obstante, en los últimos años de su vida, la preocupación del escritor por las condiciones de la civilización lo acercó a la perspectiva humanista de Mahatma (Ruiz Guadalajara, "Mahatma Gandhi en la mirada de Octavio Paz", op. cit., pp. 77-111; Paz, Vislumbres de la India, op. cit., p. 139). 
El escritor mexicano cita al activista Jayaprakash Nayaran para argumentar que India es "a nation in the making". Al comparar su experiencia histórica con la de Estados Unidos (como la bautizó Lipset, "the first new nation"), el autor enlista los obstáculos que impiden la transformación del palimpsesto indio en una nación moderna. A su juicio, la mayor amenaza para el triunfo de su proyecto nacional es la persistencia de un pasado milenario y heterogéneo en cuanto a religiones, etnias, lenguas y tradiciones. ${ }^{61}$ Según Partha Chatterjee, gran parte de los discursos poscoloniales sobre la sociedad india aún conservan su conceptualización colonial, que alimentaba la idea de su exotismo al caracterizar a su población como una mezcolanza de comunidades, imposible de adaptar a la democracia liberal ${ }^{62}$ De forma inversa, Paz considera que este sistema político es la clave para edificar un Estado-nación moderno, capaz de englobar a los diversos pueblos y religiones del subcontinente. ${ }^{63}$ Aunque propone un modelo ad hoc, inspirado tanto en la modernidad occidental cuanto en los valores endémicos de la tradición india, en realidad parece defender la predominancia de la primera sobre la segunda, al ver el secularismo como única opción para encaminar a India hacia la modernidad.

En The Nation and its Fragments, Chatterjee retoma incisivamente la terminología modernista de Benedict Anderson para denunciar que el sesgo occidental de la academia y su fetiche por la modernidad han viciado el debate sobre el nacionalismo poscolonial al intentar encajarlo en los modelos "universales" de Occidente:

Si los nacionalismos en el resto del mundo deben escoger su comunidad imaginada de entre las formas "modulares" que Europa y las Américas han puesto a su disposición, ¿qué les queda por imaginar? Pareciera que la historia ha declarado que nosotros, en el mundo poscolonial, sólo seremos consumidores perpetuos de la modernidad. Europa y las Américas, los únicos sujetos legítimos de la historia, han pensado en nuestro nombre tanto el guión de la ilustración y explotación colonial

${ }^{61}$ Paz, Vislumbres de la India, op. cit., pp. 87 y ss.

${ }^{62}$ Partha Chatterjee, "Communities and the Nation", en Saurabh Dube (ed.), Postcolonial Passages: Contemporary History-writing on India, Oxford, Oxford University Press, 2004, p. 118.

${ }^{63}$ Paz, Vislumbres de la India, op. cit., pp. 139-158. 
cuanto el de nuestra resistencia y miseria poscolonial. Incluso nuestras imaginaciones restarán por siempre colonizadas. ${ }^{64}$

Me parece que no deberíamos debatir en qué medida India puede constituirse como una nación que evoque a las europeas, sino la manera en que ésta se ha distinguido de ellas. Según Chatterjee, los nacionalismos anticoloniales de Asia y África difieren de las formas "modulares" que abanderan las sociedades occidentales, pues se conforman por dos dominios que se nutren mutuamente: la imitación material del modelo occidental (que tácitamente acepta su supremacía funcional) y la reafirmación espiritual de una identidad única, que antepone la singularidad cultural a la emulación burocrática. Esta articulación binaria de la identidad india desemboca en un proyecto distinto al que Paz visualiza, pues la espiritualidad que él disocia del nacionalismo moderno es, en realidad, una expresión de resistencia cultural ante las jerarquías globales de poder. Su objetivo no es crear una nación con base en las pautas ajenas de Europa ni recluirse en el tradicionalismo, sino crear una cultura nacional "moderna" que, al mismo tiempo, no sea occidental. ${ }^{65}$

Desde la publicación de Vislumbres de la India hace dos décadas, han surgido perspectivas revisionistas que cuestionan el valor inherente del secularismo ante la persistencia de conflictos étnicos, como los disturbios de Gujarat en 2002. Después de todo, éste no es un concepto anclado a la cultura vernácula de las sociedades indias. Dice Ashis Nandy que el lenguaje hegemónico del secularismo es una expresión del "imperialismo de categorías”, cuya etnofobia busca sepultar la heterogeneidad cul-

${ }^{64}$ Partha Chatterjee, The Nation and its Fragments: Colonial and Postcolonial Histories, Princeton, Princeton University Press, 1993, pp. 3-5.

${ }^{65}$ Ibid., pp. 5-7. Como observa Dube, el nacionalismo anticolonialista de India cuestionó directamente las concepciones eurocéntricas del fenómeno, pues revirtió los principios de la Ilustración y demás nociones occidentales para transformar los ideales de la nación soberana y el ciudadano libre en una construcción discursiva sobre la patria subyugada y el súbdito colonizado. El autor añade que, si bien las concepciones de la patria colonizada permitieron elaborar la nación en diversas formas comunitaristas, al mismo tiempo su sustitución por una visión dominante del Estado moderno estuvo moldeada por las oposiciones binarias que yacen en el corazón de la historia universal y la modernidad occidental (Saurabh Dube, Sujetos subalternos, tr. G. Franco y A. Bartra, México, El Colegio de México, 2001, p. 23). 
tural y étnica bajo el manto del Estado-nación moderno, inexorablemente vinculado al desarrollo y el progreso científico. ${ }^{66}$ De igual manera, Chakrabarty precisa que el deseo de separar necesariamente la esfera pública y la privada emana de una noción eurocéntrica de la ciudadanía que ignora otras formas de interacción entre el individuo y la comunidad. ${ }^{67}$ Tras el deseo de secularizar India yace la idea de emular al "hombre occidental”, quien pareciera haber conquistado su territorio por tener una comprensión superior sobre la relación (o, más bien, la disociación) entre política y religión. ${ }^{68}$ Lo cierto es que las comunidades religiosas de India convivieron en relativa armonía durante siglos. Como sostiene Nandy, quizá los principios cotidianos de la tolerancia religiosa en la India precolonial puedan renovar su cultura política contemporánea, más que el sueño burocrático de la "desetnización" ${ }^{99}$ que Paz considera la única salvación. ${ }^{70}$

\section{El laberinto de la modernidad}

A todos los juicios de Octavio Paz sobre India - paisajes inmutables, ausencia de conciencia histórica, cristalización de las castas, imposibilidad de formar una nación- subyace el debate de la modernidad, uno de los ejes principales de su obra ensayística y poética. No es coincidencia que ésta sea la protagonista del discurso que dio en Estocolmo al aceptar el Premio Nobel de Literatura en 1990, donde reveló que la aspiración de ser un hombre de su tiempo desembocó en la vocación de ser un poeta "moderno". En aquel discurso, el galardonado escritor definía la modernidad como una aspiración, en vez de un

${ }^{66}$ Ashis Nandy, "Closing the Debate on Secularism: A Personal Statement", en Anuradha Dingwaney Needham y Rajeswari Sunder Rajan, The Crisis of Secularism in India, Durham-Londres, Duke University Press, 2007, pp. 107-112.

${ }^{67}$ Chakrabarty, "La poscolonialidad y el artilugio de la historia", op. cit., p. 638.

${ }^{68}$ Nandy, "The Politics of Secularism...", op. cit., pp. 330 y ss.

${ }^{69}$ Ashis Nandy, "Closing the Debate on Secularism", op. cit., pp. 112-115.

70 Dice el escritor: "Entre secularismo y democracia hay una correspondencia íntima. Un Estado democrático no secular no es realmente democrático; un Estado secular no democrático es una tiranía. Secularismo y democracia son los dos aspectos complementarios de la herencia de Nehru" (Paz, Vislumbres de la India, op. cit., p. 154). 
estado: "un espejismo, un haz de reflejos”, pero también una pasión universal, que "desde 1850 ha sido nuestra diosa y nuestro demonio". ${ }^{71}$

Las exhortaciones del intelectual mexicano a modernizar India siguiendo modelos eurocéntricos parecen desconcertantes al escuchar sus críticas incisivas a la modernidad misma. En aquel discurso de aceptación, Paz afirmó que el concepto en sí era equívoco, incierto y arbitrario, pues cada sociedad tiene su propia definición. De igual forma, rechazó la temporalidad universal al criticar cómo la persecución del presente en Hispanoamérica procuraba importar el tiempo en que vivían "los otros", es decir, europeos y estadounidenses, hasta que la Revolución (o, dice el escritor, la revelación) mexicana desentrañó sus raíces: "México buscaba el presente afuera y lo encontró adentro, enterrado pero vivo. La búsqueda de la modernidad nos llevó a descubrir nuestra antigüedad, el rostro oculto de la nación". ${ }^{2}$ Para entonces, Bartra había denunciado que el tiempo lineal era tan mitológico como el circular; Paz llevaría la denuncia a otro plano al afirmar que la modernidad no era la antinomia de la tradición, sino una tradición en sí misma, su otro rostro, cuya vitalidad dependía de la simbiosis entre ambas: "aisladas, las tradiciones se petrifican y las modernidades se volatizan; en conjunción, una anima a la otra y la otra le responde dándole peso y gravedad" ${ }^{73}$

Me parece que este vaivén entre el abrazo y el repudio de la modernidad en la obra de Octavio Paz se debe a que - utilizando los términos ${ }^{74}$ de Dube- el poeta era simultáneamente un sujeto moderno y un sujeto de la modernidad: cómplice y crítico de la historia universal; pionero del modernismo en el margen del "desarrollo"; el único premio Nobel de Literatura

${ }^{71}$ Octavio Paz, "La búsqueda del presente" (discurso de aceptación del Premio Nobel de Literatura 1990), Nobelprize.org, Nobel Media AB 2014.

${ }^{72}$ Idem.

${ }^{73}$ Idem.

74 "Las concepciones comunes de la modernidad con frecuencia han comenzado por concebir el fenómeno en la imagen del sujeto moderno europeo y euroamericano, por lo general del género masculino. En contraposición, al hablar de sujetos de la modernidad, me refiero a los actores históricos que han participado activamente en los procesos de la modernidad, tanto en el sentido de sujetos a estos procedimientos como de sujetos que configuran dichos procesos" (Dube, Modernidad e historia, op. cit., p. 31). 
de México, un país en la periferia del mundo que lo había galardonado. Su criterio vago y contradictorio es evidente en el análisis comparado de Vislumbres, cuando afirma que los proyectos nacionales de India y México implicaron una crítica de sus pasados, que en ambos países fue ambigua porque entrañaba, al mismo tiempo, apartarse del pasado e intentar salvarlo. "Ni los indios ni los mexicanos reniegan de su pasado: lo recubren y lo repintan", declara Paz en aliteración. ${ }^{75}$ Aunque El laberinto de la soledad y Vislumbres de la India parecen extremos distantes de su obra - respecto a temporalidad, temática y espacio imaginado-, en el fondo, el mexicano estilizado y rebosante en patologías de su obra maestra no es tan distinto al indio de Vislumbres. Al discutir El laberinto con Claude Fell, el autor confesó que esta obra hablaba sobre "un México enterrado pero vivo [...] Un universo de imágenes, deseos e impulsos sepultados" ${ }^{76}$ Lo mismo puede decirse sobre el protagonista de su travesía por el subcontinente.

Aun así, al comparar ambas obras es claro su orientalismo selectivo. A pesar de todas las patologías actuales que el ensayista deriva de la espiritualidad mexicana en El laberinto, también arguye que la Conquista culminó en la "derrota de la mentalidad mágica y la cultura ritualista”. Mientras que nuestro pasado prehispánico es apenas perceptible en ruinas y monumentos, la antigua civilización de India es "una realidad que abarca y permea toda la vida social", un lastre místico que impide su modernización. ${ }^{77}$ Como sostiene Chakrabarty, frente al ideal abstracto de la modernidad enmarcado en el lente eurocéntrico, la historia de India sólo puede interpretarse en términos de carencia, ausencia o insuficiencia. ${ }^{78}$ En Posdata, Paz declara que "el mexicano no es una esencia sino una historia" bargo, en Vislumbres sugiere lo contrario sobre el indio: no es una historia, sino una esencia.

${ }^{75}$ Paz, Vislumbres de la India, op. cit., pp. 92 y ss. y 148.

${ }^{76}$ Octavio Paz, "Vuelta a «El laberinto de la soledad» (conversación con Claude Fell)", en El laberinto de la soledad, op. cit., p. 289.

77 Paz, Vislumbres de la India, op. cit., pp. 105 y ss.

${ }^{78}$ Chakrabarty, "La poscolonialidad y el artilugio de la historia", op. cit., p. 630.

${ }^{79} \mathrm{Paz}$, "Posdata”, op. cit., p. 213. 


\section{Ahora mismo}

El último año que Octavio Paz pasó como embajador de México en India contempló a distancia, intrigado, las revueltas juveniles que estallaban alrededor del mundo. "Era una rebelión contra los valores e ideas de la sociedad moderna”, pensó mientras escuchaba las noticias de la BBC en un pequeño radio portátil, desde el aislamiento en Kasauli. La explicación de aquellas agitaciones juveniles, fiebres pasajeras -concluyó-, yacía en el "subsuelo psíquico de la civilización de Occidente" ${ }^{80}$ Eran síntomas de su enfermedad. El 3 de octubre, tras enterarse de los sucesos que habían ocurrido la noche anterior en la plaza de las Tres Culturas, el embajador renunció a su cargo en protesta. ${ }^{81}$ Se despidió de India reafirmando su verdadera vocación con un poema que culminaba en la imagen de Elefanta, la cual invocaría por siempre al desempolvar los recuerdos de aquella década: "luz sobre el mar/la luz descalza sobre el mar y la tierra dormidos" ${ }^{82}$

Dos años después, el escritor publicó Posdata, revisión crítica de El laberinto de la soledad, donde discutió los acontecimientos de 1968 y confesó su desprecio hacia la idea de la modernidad. Según su diagnóstico, ésta era un:

Extraño padecimiento que nos condena a desarrollarnos y a prosperar sin cesar para así multiplicar nuestras contradicciones, encontrar nuestras llagas y exacerbar nuestra inclinación a la destrucción. La filosofía del progreso muestra al fin su verdadero rostro: un rostro en blanco, sin facciones. Ahora sabemos que el reino del progreso no es de este mundo: el paraíso que nos promete está en el futuro, un futuro intocable, inalcanzable, perpetuo. El progreso ha poblado la historia de las maravillas y los monstruos de la técnica, pero ha deshabitado la vida de los hombres. Nos ha dado más cosas, no más ser. ${ }^{83}$

${ }^{80}$ Paz, Vislumbres de la India, op. cit., p. 214.

${ }^{81}$ Ibid., pp. 217 y ss.

${ }^{82}$ Aunque Paz no lo menciona en Vislumbres de la India, una versión extendida de este poema se encuentra en Ladera este, con el título "Domingo en la isla de Elefanta”. Otra prueba de mi acierto al citar la edición posterior del poemario es que Paz reproduce esta versión, con la grafía en minúsculas. p. 220.

${ }^{83}$ Octavio Paz, "Olimpiada y Tlatelolco", en El laberinto de la soledad, op. cit., 
Para el poeta, los levantamientos de aquel año demostraron el deseo de oponer el "abora, por naturaleza explosivo y orgiástico", a la realidad petrificada e inasible del tiempo histórico. ${ }^{84}$ Después de todo, como diría en Vislumbres, el progreso metafísico que bombea sangre al reloj de la modernidad es "un permanente más allá, un futuro siempre inalcanzable e irrealizable". Buscando enfrentarse a los espejismos del desarrollo, Paz propuso recobrar el espíritu romántico de las rebeliones estudiantiles y reafirmar la virtud del presente: "El futuro es un tiempo falaz que siempre nos dice 'todavía no es hora' y que así nos niega [mexicanos e indios por igual, sujetos subalternos del mundo entero]. El futuro no es el tiempo del amor: lo que el hombre quiere de verdad, lo quiere ahora" ${ }^{85}$ Treinta años después, concluiría su denuncia a "los artilugios del tiempo" en Vislumbres de la India con la misma exhortación: "Creo que la reforma de nuestra civilización deberá comenzar con una reflexión sobre el tiempo. Hay que fundar una nueva política enraizada en el presente" ${ }^{86}$

Octavio Paz veía en el arte la única forma de rehuir a la modernidad opresiva, ya que el arte opone el acto a la aspiración, la creación a la espera, la negación a la imitación. Si bien en Vislumbres de la India el autor reitera, una y otra vez, las jerarquías hipotéticas del pensamiento colonial, en "De la crítica a la ofrenda" sostiene que los conceptos "centro" y "periferia" no pueden explicar el dinamismo creativo del arte moderno. ${ }^{87}$ En particular, la poesía, "la otra voz", es una fuente perenne de rejuvenecimiento, capaz de elucidar la verdadera naturaleza del tiempo, libre del sesgo lineal..$^{88} \mathrm{El}$ escritor pregunta y se responde al aceptar el Nobel: "¿Qué sabemos del presente? Nada o casi nada. Pero los poetas saben algo: el presente es el manantial de

${ }^{84}$ Ibid., p. 221.

${ }^{85}$ Octavio Paz, "El desarrollo y otros espejismos", en El laberinto de la soledad, op. cit., p. 255.

${ }^{86}$ Paz, Vislumbres de la India, op. cit., p. 211.

${ }^{87}$ Octavio Paz, "De la crítica a la ofrenda", en Puertas al campo, México, Universidad Nacional Autónoma de México, 1966, cit. por Yvon Grenier, From Art to Politics: Octavio Paz and the Pursuit of Freedom, Nueva York, Rowman \& Littlefield, 2001, p. 81.

${ }^{88}$ Ibid., p. 80. 
las presencias". ${ }^{89}$ Así, pues, la respuesta a "la pregunta que hace la India a todo el que la visita" no yace en Vislumbres, sino en Ladera este, colección de poemas que Paz escribió durante su estancia en India, y cuya publicación en 1969, me parece, no fue mera casualidad. ${ }^{90}$

\section{Nudo de tiempos}

Los poemas de Ladera este ${ }^{91}$ no buscan definir India; están impregnados de ella. Aunque en Vislumbres el intento de acortar las latitudes entre Occidente y Oriente culmina en el desenlace contrario, en este poemario Paz niega la alteridad entre hemisferios al abstraer y extrapolar la reconciliación de oposiciones que permea India, finalmente enalteciendo la universalidad, una especie de fraternidad cósmica que sólo el arte podría concebir. Catalina Quesada arguye que la comprensión de la mitología y la filosofía hindúes le permitieron concretar sus obsesiones poéticas: "la dialéctica entre lo lleno y lo vacío, entre lo único y lo plural, entre la otredad y la mismidad". ${ }^{92}$ De igual manera, Malabika Bhattacharya elogia la forma en que el poeta retomó

${ }^{89} \mathrm{Paz}$, "La búsqueda del presente", op. cit.

${ }^{90}$ Sobran argumentos de autoridad para justificar la intertextualidad latente en las obras de Paz. Julia Kushigian cita a Saúl Yurkievich y a Carlos Fuentes. Este último escribió en Los signos en rotación: "Los ensayos de Octavio Paz, inseparables de su poesía, no son sólo una extensión crítica de ésta; más bien, ambas formas integran un todo crítico y participan de un signo idéntico: la elaboración de un conocimiento, de un saber, por naturaleza antidogmático, de los pueblos humanos" (cit. por Kushigian, “'Ríos en la noche: fluyen los jardines”, op. cit., pp. 776-777). Y, sin embargo, en este caso no es necesario citar fuentes externas. Paz explica en la introducción de Vislumbres de la India que este libro "no es sino una larga nota al pie de página de los poemas de Ladera este", que - aunado a El mono gramático- contiene sus "memorias e invocaciones” sobre los seis años que el escritor pasó en India (Paz, Vislumbres de la India, op. cit., p. 42).

${ }_{91}$ Estoy consciente de que, en las Obras completas del autor, Ladera este, Hacia el comienzo y Blanco aparecen como colecciones separadas de poesía, con cierta autonomía y distintas fechas de creación. No obstante, he decidido interpretar los poemas que aparecen en la edición de Joaquín Mortiz sin distinguirlos entre ellos, porque - a pesar de las temáticas distintas- todos ellos comparten el trasfondo de India. Debo añadir que, debido a la extensión del texto, no he podido incluir Blanco en mi análisis, a pesar de que habría sido lo más pertinente. Eunice Hernández discute este complejísimo poema en "Octavio Paz: la India como un palimpsesto", Revista de la Universidad de México, núm. 90, 2011, pp. 83-88.

${ }_{92}$ Quesada Gómez, “De la India a las Indias y viceversa”, op. cit., p. 55. 
el budismo de Nagarjuna, "modificándolo de acuerdo con su propio credo metafísico y armonizándolo con su visión poética", para así denunciar la crisis espiritual de Occidente al negar el tiempo lineal. ${ }^{93}$ En Ladera este, India no es paria de la modernidad, sino su cura. ${ }^{94}$

Como afirma Fabienne Bradu, aquel exceso de realidad que Paz relata extenuado en el recuento de su primera visita a Bombay (hablando de mierda y jazmines) anticipa su revuelta contra el racionalismo en "el ojo de un huracán donde las dualidades violentamente contrastadas se aniquilan y los tiempos coinciden en uno solo: el presente perpetuo de la poesía". ${ }^{95}$ Así, pues, al reinterpretar "Viento entero" - que bajo el lente de Said parecería acusación orientalista de atemporalidad-, queda claro que la repetición del leitmotiv "el presente es perpetuo" no es denuncia de estancamiento, sino una alusión al "ahora mismo", aquella exhortación humanista que Paz formuló en Posdata para reprochar el eterno aplazamiento de la modernidad. Elsa Cross nota que desde "Piedra de sol" el escritor mexicano experimentó con una concepción circular de la realidad y el tiempo poético; sin embargo, en "Viento entero" el tiempo no sólo es circular, sino también discontinuo, fragmentado, simultáneo. ${ }^{96}$ Quizá sólo en esa realidad fracturada tenga sentido que Paz haya refutado los prejuicios de Vislumbres de la India en Ladera este, un libro que escribió treinta años antes. Dice Manuel Durán que "Viento entero" "aniquila el devenir y, al mismo tiempo, la idea de progreso, $\tan$ occidental", ${ }^{97}$ en versos como:

juntos atravesamos

los cuatro espacios los tres tiempos

${ }_{93}$ Bhattacharya, "Echoes of India", op. cit., pp. 1-7.

${ }^{94}$ Aunque los dos libros que he tratado aquí supuestamente se centran en India, sus títulos denotan una intención que la trasciende: en la edición de Seix Barral, Vislumbres de la India tiene el subtítulo Un diálogo con la condición humana, que refleja la intención de entablar una conversación entre hemisferios para reflexionar sobre el futuro de la humanidad. De igual manera, es una coincidencia amena que Ladera este se haya publicado en la colección de poesía de la editorial Joaquín Mortiz titulada Las Dos Orillas, un guiño incidental a su relación con la "ladera oeste".

${ }_{95}$ Bradu, "Persistencia de la India en Octavio Paz", op. cit., p. 29.

${ }^{96}$ Elsa Cross, "El erotismo y lo sagrado en Paz", en Martínez Ruiz y Rosado Moreno (coords.), Festines y ayunos, op. cit., p. 22.

${ }^{97}$ Durán, "La huella del Oriente en la poesía de Octavio Paz", op. cit., p. 114. 
pueblos errantes de reflejos

y volvimos al día del comienzo

El presente es perpetuo [...]

los universos se desgranan

un mundo cae

se enciende una semilla

cada palabra palpita [...]

arranca sus raíces el mundo

Gira el espacio

no pesan más que el alba nuestros cuerpos

tendidos. $^{98}$

Asimismo, Bhattacharya considera que llamar "idea fija” a Delhi en "El balcón" no implica que esté varada en el tiempo, como afirmé antes, sino que denota la confluencia del pasado, el presente y el futuro que Paz considera necesaria en una articulación desoccidentalizada de la modernidad. ${ }^{99}$ Basta recordar aquella reflexión sobre el movimiento y la inmovilidad en $E l$ mono gramático, cuando el ensayista concluye que "la fijeza nunca es enteramente fijeza y que siempre es un momento del cambio". ${ }^{100}$ De igual manera, añade en "Vrindaban" que "Los absolutos las eternidades/Y sus aledaños" no le conciernen, ya que su interés lírico se centra en el "Advenimiento del instante/ $\mathrm{El}$ acto/El movimiento en que se esculpe/Y se deshace el ser entero" ${ }^{101}$ En el discurso del Nobel reafirmaría esta aseveración, al proclamar que la experiencia poética es el instrumento para crear una filosofía del presente - distinta a la modernidad occidental, la filosofía del porvenir-, ya que "la reflexión sobre el ahora no implica renuncia al futuro ni olvido del pasado: el presente es el sitio de encuentro de los tres tiempos". ${ }^{102}$ Entonces la eternidad no es tiempo inmóvil, sino permanencia dinámica, y la modernidad no es un hilo infinito, sino un "nudo de tiempos, racimo de espacios”, como la noche que el poeta describe en "Perpetua encarnada". ${ }^{103}$

\footnotetext{
${ }_{98} \mathrm{Paz}$, "Viento entero", en Ladera este, op. cit., pp. 101-108.

${ }^{99}$ Bhattacharya, "Echoes of India", op. cit., p. 8.

100 Paz, El mono gramático, op. cit., pp. 25-30.

101 Octavio Paz, "Vrindaban", en Ladera este, op. cit., p. 62.

${ }^{102} \mathrm{Paz}$, "La búsqueda del presente”, op. cit.

${ }^{103}$ Octavio Paz, "Perpetua encarnada", en Ladera este, op. cit., p. 39.
} 


\section{Dos orillas}

Dice Octavio Paz en El mono gramático: "el poeta no es el que nombra las cosas, sino el que disuelve sus nombres". ${ }^{104}$ Así como Bartra destaca la forma en que las jerarquías del tiempo lineal se convirtieron en divisiones metageográficas, Paz insinúa que al desarticularlas también desvanecerán las fronteras imaginadas entre Este y Oeste. Diversos autores coinciden en que el poeta trasciende ambas barreras al apropiarse de aforismos budistas que reconcilian oposiciones. Dice Bhattacharya que "Ladera este es la aceptación final del principio budista según el cual dualidad y oposición son meras ilusiones, maya, porque una existe en la otra y ambas en una, que es en sí la nada o sunyata" ${ }^{105}$ Por su parte, Kushigian sugiere que "la otra orilla" a la que alude Paz refleja el concepto budista del salto simbólico, "la representación gráfica y metafórica del contacto entre los dos extremos"; por ello, al hablar de una, más bien se alude a "las dos orillas', la confluencia entre elementos opuestos, su continuidad, y contigüidad en tiempo y espacio". ${ }^{106}$ No hay dos laderas, sino el río entre ellas, que fluye rítmicamente de una bahía a otra, acarreando en su vaivén granos de arena, retornando sin partir, "como la imagen geométrica de la Banda de Möbius". ${ }^{107}$

Aunque Paz escribió la mayor parte de los poemas en $\mathrm{La}$ dera este durante sus viajes por el subcontinente asiático, evitó aislarlo al establecer un diálogo continuo con Occidente. ${ }^{108} \mathrm{Ex}$ plica Manuel Durán que su interés hacia Oriente era parte de su "humanismo comprometido", ya que buscaba herramientas para entender las patologías del hombre occidental. ${ }^{109}$ En el pai-

${ }^{104}$ Paz, El mono gramático, op. cit., p. 96.

105 Bhattacharya, "Echoes of India", op. cit., p. 17.

${ }^{106}$ Kushigian, “'Ríos en la noche: fluyen los jardines”, op. cit., p. 776.

107 Idem.

${ }^{108}$ Esto es más obvio en los cuatro poemas titulados "Intermitencias del Oeste”. Considerando el trasfondo histórico de la Guerra Fría, resulta irónico que la primera de estas intromisiones occidentales sea una "canción rusa". Me parece que esto refuerza la idea de que la Ladera este a la que se refiere Paz es, esencialmente, oriental.

${ }^{109}$ Durán, "La huella del Oriente en la poesía de Octavio Paz", op. cit., p. 108. El autor añade que la síntesis hemisférica que Paz logra en Ladera este no sólo se debe al espíritu del poemario, sino también a su cuerpo: Paz entremezcla la puntuación y disposición de la poesía modernista con las formas orientales de "cuasi-haikais". 
saje árido de India, el poeta tropieza con Artemisa, compara la voz del nim con la del fresno, vanagloria personajes célebres de la Revolución mexicana y protestas anticapitalistas en París, e incluso arguye (al divagar sobre música y silencio) que John Cage era japonés. "Imágenes de uno y otro lado del océano fungen como versiones recíprocas, como metáforas mutuas. El poema está alimentado por una colectividad y, en consecuencia, es universal, nunca localista", ${ }^{110}$ dice Muñoz García, a lo que Durán añadiría: “el carácter de la cultura hindú es abierto, sincrético, acumulativo y, por tanto, estos detalles, estas 'formas decorativas' o interferencias occidentales, se funden perfectamente en un conjunto continuo y en cierto modo amorfo -deliberadamente amorfo". ${ }^{111}$

Si bien el contraste entre hemisferios permite evitar la soledad, la relación específica entre México e India es plena hermandad. Algunas veces, Paz rechaza conscientemente el orientalismo y otras lo neutraliza al "orientalizarse” a sí mismo. Esto es evidente en el primordialismo con el que denuncia la masacre de Tlatelolco en "Intermitencias del Oeste (3)", donde conjuga nuevamente el tiempo en un nudo, una modernidad tradicional, que entrelaza con ironía ofrendas sangrientas del pasado y el presente: "(Los empleados/municipales lavan la sangre/en la Plaza de los Sacrificios)”. ${ }^{112}$ Así, pues, el autor se distancia de los prejuicios que prevalecen en Vislumbres al reconocer su propio exotismo y equiparar ambos en reflejos intercalados. La ambigüedad de la peregrinación religiosa que observa en "Cochin" basta para disolver ambos hemisferios por un instante:

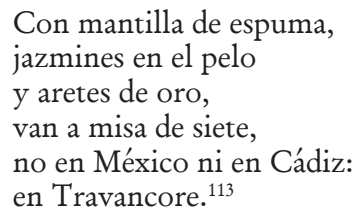

${ }^{110}$ Muñoz, "Vislumbres del Oriente, o la India traducida por Paz", op. cit., p. 148.

${ }^{111}$ Durán, "La huella del Oriente en la poesía de Octavio Paz", op. cit., p. 110.

112 Octavio Paz, "Intermitencias del Oeste (3)", en Ladera este, op. cit., p. 68. La ironía no tenía límites en la obra del poeta. El número de página habría sido una decisión consciente.

113 Octavio Paz, "Cochin”, en ibid., p. 46. 
Lo más fascinante ocurre cuando el diálogo entre exotismos deviene soliloquio a dos voces. El poema que Paz dedica al afamado pintor indio Jagdish Swaminathan (uno de sus amigos más cercanos durante su periodo como embajador) elogia la visceralidad del modernismo contrapuesta a la racionalidad de la modernidad, al narrar cómo el artista destruye "la idea fija" con un trapo y un cuchillo. Sus versos tienden un puente (¿o torrente?) entre periferias al compaginar sus matices y deidades en el espíritu creador del hombre frente al lienzo: "salta el rojo mexicano/y se vuelve negro/salta el rojo de la India/y se vuelve negro [...] /el cuerpo azul de Kali/el sexo de la Guadalupe". ${ }^{114}$

"Viento entero" y "Al pintor Swaminathan" son ejemplos brillantes de la identificación periférica que el orientalismo latinoamericano encierra; además, revelan la importancia del erotismo en esta correspondencia paciana. ${ }^{115}$ No debe olvidarse que Ladera este abre con una dedicatoria a Marie José. En diversos poemas, la llama doble aparece como metáfora de la reconciliación entre opuestos; el afecto que encierran dos cuerpos desnudos se equipara a la conjunción de tiempos o lugares. La disolución erótica de tiempo y espacio que impera en este poemario culmina en "Cuento de dos jardines". Mientras que en El mono gramático, el viajero atravesaba fronteras distantes al pasar de Galta a Cambridge sin dificultad, en este poema transita patios que décadas y kilómetros han separado. Los jardines a los que el poeta alude son memorias: el primero es el jardín de la casa en la Ciudad de México donde pasó su infancia ("Aquel de Mixcoac, abandonado,/cubierto de cicatrices,/era un cuerpo/a punto de desplomarse.") y el segundo es el jardín aledaño a la embajada de México en India, donde se casó con

${ }^{114}$ Octavio Paz, “Al pintor Swaminathan”, en ibid., pp. 22 y ss.

115 Anil Dhingra reflexiona sobre el poema "Domingo en la isla de Elefanta" respecto al uso del erotismo en la reflexión divina: "Paz emplea Maithuna, el momento del amor sexual entre Shiva y Parvati como una metáfora para expresar la idea de la unión de los contrarios. Constituye una nueva representación del primer acto de creación [...] Paz une las polaridades de hombre-mujer, día-noche, negro-blanco" (Anil Dhingra, "La India en la obra de Octavio Paz. Algunas reflexiones", en Isaías Lerner, Robert Nival y Alejandro Alonso (eds.), Actas del XIV Congreso de la Asociación Internacional de Hispanistas, Nueva York, 16-21 de julio de 2001, t. IV: Literatura Hispanoamericana, Newark, Juan de la Cuesta, 2004, p. 164). 
Marie José al pie de un árbol de nim ${ }^{116}$ y renació ("Nosotros le pedimos al nim que nos casara./Un jardín no es un lugar:/es un tránsito/una pasión”). ${ }^{117}$ Kushigian considera que esta obra "simboliza proféticamente la sensación de andar a la deriva entre 'las dos orillas' y la vertiginosa mezcla de opuestos". ${ }^{118}$ Desde el edén de recuerdos, Paz nuevamente identifica deidades ajenas, y las transmuta en un solo credo y espacio al encajar a Prajnaparamita en el culto guadalupano, cual madre universal. Así, pues, México e India se miran a través de un espejo para encontrarse en el mismo sitio, como hermanos reconciliados o amantes provisionales, ladera este, ladera oeste. En palabras de Elsa Cross, este poema triunfa en "la aprehensión de lo trascendente dentro de lo inmanente. La unión de estos dos opuestos hace desvanecer toda dualidad y escisión no sólo de la realidad externa, sino del ser humano consigo mismo". ${ }^{119}$

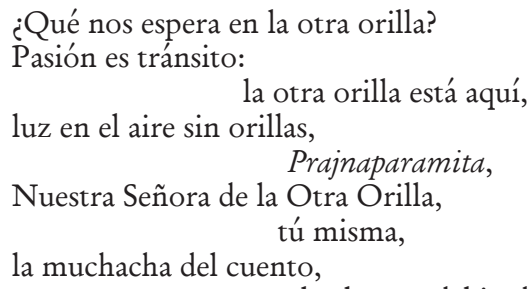
la alumna del jardín. ${ }^{120}$

"Transcurrir es quedarse", dice Paz, y disuelve finalmente la cartografía de lo encantado. En "Cuento de dos jardines", el poeta mexicano desmantela los prejuicios inherentes a la noción de la historia universal que divide el mundo en dos, al desentrañar la naturaleza inasible de estos espacios. Finalmente, halla

${ }^{116}$ Fabienne Bradu hace una observación curiosa al respecto. Desde su primera noche en Bombay, Paz pidió auxilio al tronco de un árbol, extenuado ante las apariciones violentas e inesperadas. El espíritu poético de este sujeto aparecerá repetidas veces en su poesía, con particular acento en Ladera este, como en "Dónde sin quién” y, por supuesto, en "Cuento de dos jardines" (Bradu, "Persistencia de la India en Octavio Paz”, op. cit., pp. 28 y ss.).

${ }_{117}$ Octavio Paz, "Cuento de dos jardines", en Ladera este, op. cit., pp. 130-141.

${ }_{118}$ Kushigian, “Ríos en la noche: fluyen los jardines”, op. cit., p. 777.

119 Cross, "El erotismo y lo sagrado en Paz", op. cit., p. 24.

${ }^{120} \mathrm{Paz}$, "Cuento de dos jardines", en Ladera este, op. cit., p. 139. En esta versión, se modificaron la puntuación, la grafía y la disposición espacial de los versos. 
en la itinerancia el "tiempo del amor" que no encontraba en el futuro. En camino a Galta, el viajero descubre que, en realidad, buscaba el tránsito en sí: "Para aquellas colinas éramos unos extraños, como los primeros hombres que, hacía milenios, las habían recorrido. Pero los que caminaban conmigo no lo sabían: habían abolido la distancia —el tiempo, la historia, la línea que separa al hombre del mundo". ${ }^{121} \mathrm{Ni}$ aquellas colinas ni los jardines del cuento eran temporales o espaciales:

Una casa, un jardín,

no son lugares:

giran, van y vienen.

abren en el espacio

Sus apariciones

otro tiempo en el tiempo.122

\section{Pájaros}

Vislumbres de la India concluye con un apéndice de poemas indios que el escritor mexicano tradujo al español a partir de versiones en inglés. ${ }^{123}$ No obstante, Adrián Muñoz observa que "uno tiene la legítima impresión de estar leyendo a Paz más que a los autores indios que intenta difundir" ${ }^{124}$ Esta observación podría extenderse a la relación general del autor con el subcontinente: Paz no traduce fielmente su realidad para el público, sino que la abstrae poéticamente; interpreta, recrea y se apropia de India tanto como ella se apropió de él. Aunque cede a las trampas retóricas de la modernidad en Vislumbres de la India y las disuelve en Ladera este, ambas obras están guiadas por un instinto más visceral que cerebral. Él mismo confiesa que el primero "no es hijo del saber, sino del amor”, ${ }^{125}$ y por ello sus descripciones de

${ }^{121}$ Paz, El mono gramático, op. cit., p. 80.

${ }^{122} \mathrm{Paz}$, "Cuento de dos jardines", en Ladera este, op. cit., p. 130.

${ }^{123}$ Esto no ocurre en la edición original, pero sí en Octavio Paz, Vislumbres de la India, Barcelona, Galaxia Gutenberg, 1997. Si el lector aún no tiene una edición de este libro, debo añadir que ésta es considerablemente más bella que la original, de Seix Barral.

${ }^{124}$ Muñoz, "Vislumbres del Oriente, o la India traducida por Paz", op. cit., p. 135.

125 Paz, Vislumbres de la India, op. cit., p. 41. 
pueblos y costumbres indios evocan capítulos de Las ciudades invisibles, en vez de su realidad tangible.

Creo que Paz estaba tan consciente de su orientalismo que optó por instrumentalizarlo, lo que le permitió nutrir su ánimo creativo. Él mismo explica que Vislumbres buscaba responder la pregunta: “¿Cómo ve un escritor mexicano, a fines del siglo xx, la inmensa realidad de la India?”, lo que reafirma la idea de que esta obra trata sobre percepciones, quimeras, ciudades de arena y asombro. Quizá el deseo de idealizar el subcontinente suponía que las metageografías en que el mundo se divide están tan arraigadas en nuestro imaginario que, a estas alturas, es imposible demolerlas, por lo que es más fácil construir sobre ellas y recorrerlas de principio a fin. Como bien dijo Paz al recibir el Nobel, la modernidad no se encuentra en un hemisferio ni en el otro y no yace en un tiempo, sino en todos. "La abrazamos y al punto se disipa: sólo era un poco de aire. Es el instante, ese pájaro que está en todas partes y en ninguna. Queremos asirlo vivo pero abre las alas y se desvanece, vuelto un puñado de sílabas". ${ }^{126}$ Extraña coincidencia: entre todas las palabras que se repiten en Ladera este (comienzo, cuerpo, silencio...), una aparece más de veinte veces, ${ }^{127}$ misma que el poeta mexicano advierte - aunque sea por un instante- en "Los jardines de los Lodi”. Incluso las imágenes que creemos eternas pueden cobrar vida sin previo aviso y disiparse en seguida:

En el azul unánime

los domos de los mausoleos

-negros, reconcentrados, pensativosemitieron de pronto

$$
\text { pájaros. }{ }^{128}
$$

${ }^{126}$ Paz, "La búsqueda del presente”, op. cit.

127 'En Ladera este, palabras como 'silencio', 'comienzo', 'mismo' y 'mujer' se repiten frecuentemente, pero la palabra 'pájaro' atraviesa la antología y aparece más de veinte veces. En esta nueva dimensión de [la poesía de Octavio Paz], tiempo y espacio son conquistados y el 'pájaro' se manifiesta como una palabra simbólica que nos permite atravesarlos" (Susnigdha Dey, "Indian Themes in Neruda and Paz", Indian Literature, vol. 19, núm. 2, marzo-abril de 1976, p. 21).

${ }^{128}$ Octavio Paz, "En los jardines de los Lodi”, en Ladera este, op. cit., p. 24. 
Dirección institucional del autor:

Centro de Estudios Internacionales

El Colegio de México

Carretera Picacho Ajusco 20

Ampliación Fuentes del Pedregal

14110, Ciudad de México

\section{Bibliografía}

AstaIn, Aurelio (ed.), Japón en Octavio Paz, México, Fondo de Cultura Económica, 2014.

Banerjee-Dube, Ishita, Religion, Law and Power: Tales of Time in Eastern India, 1860-2000, Londres, Anthem, 2007.

BARTRA, Roger, La jaula de la melancolía: identidad y metamorfosis del mexicano, México, Grijalbo, 1987.

Bhattacharya, Malabika, "Echoes of India: The Poems of Octavio Paz", India International Centre Quarterly, vol. 25, núm. 1, 1989, pp. 1-19.

Bradu, Fabienne, "Persistencia de la India en Octavio Paz", en Xicoténcatl Martínez Ruiz y Daffny Rosado Moreno (coords.), Festines y ayunos. Ensayos en homenaje a Octavio Paz (1914-2014), México, Instituto Politécnico Nacional, 2014, pp. 27-37.

BRIANTE, Susan, "Dwelling and Travel: Octavio Paz and El mono gramático", TRANS-, núm. 5, 31 de enero de 2008. [<trans.revues. org/243>, consultado el 5 de septiembre de 2015]. DOI: 10.4000 /trans.243.

Calvino, Italo, Las ciudades invisibles, $23^{\text {a }}$ ed., tr. A. Bernárdez, Madrid, Siruela, 2013.

Chakrabarty, Dipesh, "La poscolonialidad y el artilugio de la historia: ¿quién habla en nombre de los pasados “indios'?”, en Saurabh Dube (ed.), Pasados poscoloniales: colección de ensayos sobre la nueva historia y etnografía de la India, tr. G. F. Toriz, México, El Colegio de México, 1999, pp. 623-658.

Chatterjee, Partha, "Communities and the Nation", en Saurabh Dube (ed.), Postcolonial Passages: Contemporary History-writing on India, Oxford, Oxford University Press, 2004, pp. 115-131.

ChatterJee, Partha, The Nation and its Fragments: Colonial and Postcolonial Histories, Princeton, Princeton University Press, 1993.

Cross, Elsa, "El erotismo y lo sagrado en Paz", en Xicoténcatl Martínez Ruiz y Daffny Rosado Moreno (coords.), Festines y ayunos. 
Ensayos en homenaje a Octavio Paz (1914-2014), México, Instituto Politécnico Nacional, 2014, pp. 17-26.

Dey, Susnigdha, "Indian Themes in Neruda and Paz", Indian Literature, vol. 19, núm. 2, marzo-abril de 1976, pp. 11-24.

Dhingra, Anil, "La India en la obra de Octavio Paz. Algunas reflexiones", en Isaías Lerner, Robert Nival y Alejandro Alonso (eds.), Actas del XIV Congreso de la Asociación Internacional de Hispanistas, Nueva York, 16-21 de julio de 2001, t. IV: Literatura Hispanoamericana, Newark, Juan de la Cuesta, 2004, pp. 161168.

Dirks, Nicholas B., "Castes of Mind", Representations, vol. 37, núm. 1, 1992, pp. 56-78.

DuBE, Saurabh, "Espacios encantados y lugares modernos", en Saurabh Dube et al. (coords.), Modernidades coloniales: otros pasados, historias presentes, tr. A. Bartra, México, El Colegio de México, 2004, pp. 99-118.

Dube, Saurabh, Modernidad e historia: cuestiones críticas, tr. A. Muñoz, México, El Colegio de México, 2011.

Dube, Saurabh, Sujetos subalternos, tr. G. Franco y A. Bartra, México, El Colegio de México, 2001.

DurÁn, Manuel, "La huella de Oriente en la poesía de Octavio Paz", Revista Iberoamericana, vol. 37, núm. 74, 1971, pp. 97-116.

Grenier, Yvon, From Art to Politics: Octavio Paz and the Pursuit of Freedom, Nueva York, Rowman \& Littlefield, 2001.

Hernández, Eunice, "Octavio Paz: la India como un palimpsesto", Revista de la Universidad de México, núm. 90, 2011, pp. 83-88.

Kushigian, Julia A., "'Ríos en la noche: fluyen los jardines': Orientalism in the Work of Octavio Paz", Hispania, vol. 70, núm. 4, 1987, pp. 776-786.

Mitchell, Timothy, “The Stage of Modernity”, en Timothy Mitchell (ed.), Questions of Modernity, Minneapolis, University of Minnesota Press, 2000, pp. 1-34.

MuÑoz García, Adrián, "Vislumbres del Oriente, o la India traducida por Paz", en Xicoténcatl Martínez Ruiz y Daffny Rosado Moreno (coords.), Festines y ayunos. Ensayos en homenaje a Octavio Paz (1914-2014), México, Instituto Politécnico Nacional, 2014, pp. 113-153.

NANDY, Ashis, "Closing the Debate on Secularism: A Personal Statement", en Anuradha Dingwaney Needham y Rajeswari Sunder Rajan, The Crisis of Secularism in India, Durham-Londres, Duke University Press, 2007, pp. 107-117.

NAndy, Ashis, "The Politics of Secularism and the Recovery of Re- 
ligious Toleration", en Rajeev Bhargava (ed.), Secularism and its Critics, Delhi, Oxford University Press, 1998, pp. 321-344.

NeHru, Jawaharlal, The Discovery of India, Nueva York, The John Day Company, 1946.

PAz, Octavio, "La búsqueda del presente" (discurso de aceptación del Premio Nobel de Literatura 1990), Nobelprize.org, Nobel Media AB 2014. [ < nobelprize.org/nobel prizes/literature/laureates/1990/paz-lecture-s.html >, consultado el 4 de diciembre de 2015.]

Paz, Octavio, Ladera este, México, Joaquín Mortiz, 1969.

Paz, Octavio, Ladera este, $5^{\text {a }}$ ed., México, Joaquín Mortiz, 1998.

Paz, Octavio, El laberinto de la soledad, México, Fondo de Cultura Económica, 2007.

Paz, Octavio, El mono gramático, México, Seix Barral, 1974.

PAz, Octavio, Obras completas VII: Obra poética (1935-1998), $2^{\mathrm{a}}$ ed., Barcelona, Galaxia Gutenberg, 2004.

Paz, Octavio, Vislumbres de la India, Barcelona, Galaxia Gutenberg, 1997.

PAz, Octavio, Vislumbres de la India, Barcelona, Seix Barral, 1995.

PratT, Mary Louise, Imperial Eyes: Travel Writing and Transculturation, Nueva York-Londres, Routledge, 1993.

Quesada Gómez, Catalina, "De la India a las Indias y viceversa: relaciones literarias entre Hispanoamérica y Asia (siglo xx)", Iberoamericana. América Latina-España-Portugal, vol. 11, núm. 42, 2011, pp. 43-63.

Ruiz Guadalajara, Juan Carlos, "Mahatma Gandhi en la mirada de Octavio Paz", en Xicoténcatl Martínez Ruiz y Daffny Rosado Moreno (coords.), Festines y ayunos. Ensayos en homenaje a Octavio Paz (1914-2014), México, Instituto Politécnico Nacional, 2014, pp. 77-111.

SAID, Edward, Orientalism, Nueva York, Pantheon, 1978.

SweENEY, John A., "Postnormal Imaginings in Wes Anderson's The Darjeeling Limited”, East-West Affairs, vol. 2, núm. 1, 2013, pp. 75-98.

TINAJERO, Araceli, Orientalismo en el modernismo hispanoamericano, West Lafayette, Purdue University Press, 2003. 
